\title{
Sister Nivedita: The Embracer of India
}

\author{
Squadron Leader Toolika Rani (Retd.) \\ Research Scholar, Dept. of History, \\ Baba SahebBhimrao Ambedkar University, Lucknow \\ Email: tulich83@gmail.com
}

\begin{abstract}
Nineteenth century was the time of renaissance in the socialcultural landscape of India. Several prominent Indians realized the significance of Indian knowledge and endeavoured to reignite the cultural pride. This resurgence was a reaction to years of systematically imposed mental slavery. After Macaulay's considerably successful efforts to create a race Indian only in blood but British in taste, language and ideas, the revival of Indian consciousness was an important phenomena. While it was natural for an Indian to take pride in her cultural heritage, a foreigner stands tall in the list of those who contributed immensely in igniting that awareness and disseminating it through tireless efforts. Sister Nivedita, an Irish lady not only respected Indian culture, she embodied it. She reminded those who had begun aping the west of their own greatness. She chose education as the vehicle of her service to India. Contrary to many Indian intellectuals of the time who considered western education as the only means to eradicate the prevalent social evils, her idea of education was seeped in the native traditions and not of uprooting everything old and transplanting everything afresh. Women remained much at the focus of her work. She maintained that Indian women, contrary to the prevalent notions, were not ignorant. They were empowered in a unique way and had immense strength of character, faith, compassion and service to others. She ensured to assimilate the traditional character of womanhood, and the element of spirituality in their modern education. Even at the risk of her own life she dedicated herself to the cause of poor and downtrodden, during the Plague in Calcutta and the Bengal famine in 1906. The study of her works would help in understanding not only Indian renaissance in deeper context but also the position of women in that period. This paper would like to analyse Sister Nivedita's work in
\end{abstract}

Reference to this paper should be made as follows:

Received: 17.08.2020

Approved: 30.09.2020

Sqn. Ldr. Toolika Rani (Retd.)

Sister Nivedita: The Embracer of India

Article No. 30

RJPSS Sept. 2020,

Vol. XLV No. 2, pp. 251-258

Online available at: https://anubooks.com/ ripss-2020-vol-xlv-no-2/

https://doi.org/10.31995/

rjpss.2020.v45i01.030

Key words: Renaissance, culture, education, women, service 
Sister Nivedita: The Embracer of India

Sqn. Ldr. Toolika Rani (Retd.)

Transition from medievalism to modern capitalism in India saw socio-religious reform movements aiming at remodeling of old religion to suit the new social needs of the time. Indian awakening was basically to reform the many social evils which had crept into our society as well as religion. Primarily the aim was to reform the life of individuals through education. The prominent torch bearers of this renaissance were Raja Ram Mohan Roy, DayanandSaraswati, Swami Vivekananda and Sister Nivedita, a person who has a special place in Indian History.

Sister Nivedita whose original name was Margaret Elizabeth Noble, was a Scot Irish social worker, author, teacher and disciple of Swami Vivekananda. She was named Nivedita which means dedicated to God. In 1895 Swami Vivekananda introduced her to east and teachings of oriental culture. Lizelle Raymond, her biographer writes, "She had at last discovered a religion whose foundations, classification of elements, and forms of worship could be discussed scientifically; a religion which consistently maintained contact between spiritual and practical life through the medium of experience. Such a religion relied exclusively on what was noblest and best in mankind that quality of spiritually progressive freedom as opposed to sin-entagled slavery. As Margaret analysed these reasons, with considerable lucidity, she declared herself the Swami's disciple by addressing him as "Master". She had understood that Swami Vivekananda lived for the Truth, and that he would serve It wherever It was to be found". 'Therefore, inspired by his ideals, she also merged her path with his and decided to dedicate her life to the nation and culture he adored. When asked by Swami Vivekananda, "What will be your future work in India?" she replied, "My life is given to India. In it I shall live and die."2

Her admiration for Vivekananda led to an all-embracing love for India which was then under the British rule. The whites here were dismissive of her, the erudite Indians accepted her but she had to face the rigidities of the orthodox Hindu society. However, in her letter to Sara Bull, she writes how Sarada Devi, the wife of Ramakrishna Paramhansa, would accept her- calling her amarmeye(my daughter) - and even sharing food with her, Mrs. Bull and Miss Macleod. "This gave us all the dignity and made my future work possible in a way nothing else possibly could have done," she later wrote in a letter. ${ }^{3}$ She strongly believed that without robust roots, a tree cannot be expected to flourish well. That's why she imbibed the oriental spirituality and concept of service in her own conduct which helped ease people's hesitation in receiving knowledge from a foreigner. She no longer remained an outsider but merged within the multitude of Indian masses, and worked to uplift them from within.

\section{Sister Nivedita and Indian Womanhood}

She held a high opinion of Indian women and her ideal was holy mother Sharda Devi.Observing her she learnt self-denial and selflessness. Mother was closest to her heart and she was mother's dear 'khooki'. In her presence she behaved like 
RJPSS Sept. 2020 Vol. XLV No.2, ISSN: (P)0258-1701 (e)2454-3403 Impact Factor: 7.717

https://doi.org/10.31995/rjpss.2020.v45i01.030 a child basking in mother's affection, relishing the small presents which she made for her. She wrote, "To me it has always appeared that she is Sri Ramakrishna's final word as to the ideal of Indian womanhood. But is she the last of an old order, or the beginning of a new? In her, one sees realized that wisdom and sweetness which the simplest woman may attain. And yet, to myself, the stateliness of her courtesy and her great open mind are almost as wonderful as her sainthood. I have never known her hesitate, in giving utterance to large and generous judgement, however new or complex might be the question put before her. Her life is one long stillness of prayer." 4

She always addressed women in India as "our women", praising the faithful of the Indian wife and utter selflessness and loving nature of Indian mother. She was against the notion that Indian women are ignorant and oppressed. In a letter written for a Madras women's gathering, she wrote that it was Swami Vivekananda's conviction that the future of India depended more on Indian women than on Indian men. She wanted them to get educated but it should be a national and creative education. The women who were going to universities at that time were only influenced by western thoughts and civilization. She wanted the education in which nation should become central point of existence in men's as well as women's life. She emphasized that Indian women should remain Tapaswinibut also participate in nation-building by enlarging and expanding their concern of family to the nation. The motive of taking care of the family shall be to contribute in the strength of the nation.

\section{Contribution in Women's Education}

Inspired by Swami Vivekananda's conviction that women were at the core of a nation's progress, she dedicated her efforts towards their education.But she adopt a superiority approach while dealing with the netizens. Speaking during her very first address in India, she emphasized that she was there to serve India, that it was India's inherent greatness and wisdom that had brought her to this land and despite being of immense literary acumen and stature in the west, she considered that her own education had just begun. Teaching was very close to Nivedita's heart and she broke new grounds in this respect, before she set sail. What attracted Nivedita to Vivekananda (who held sessions in London in 1895-96) was not only his talk on Vedanta but also his thoughts on girl's education in India. She was moved enough to leave her home for India to serve the girl child there. Nivedita who spent thirteen years in India till her death, opened a school in 1898, going from door to door pleading with parents to send their girls to her school. ${ }^{5}$ Stimulation of thought regarding the importance of women education was the most challenging in prevailing socio-religious milieu, where women's main arena was considered the home and not the school or public life but Nivedita persisted in her efforts and the school began to see a higher attendance. Though working with meagre resources, she instilled a wealth of 
Sister Nivedita: The Embracer of India

Sqn. Ldr. Toolika Rani (Retd.)

knowledge in their minds which opened up new areas of exploration in the realms of thought and social experiment, widening their circle of existence and influence. The groundwork for women's later participation in the national struggle for freedom was being done by Nivedita.

\section{A Prolific Writer}

Nivedita shared her thoughts on varied aspects of Indian life with eminent people within India and abroad. There is a treasure trove of her letters written during 1898 and 1911, which throw light on her multifaceted personality and her works in India. She wrote the letters almost like a diary to her family, friends and acquaintances across the globe. The recipients include eminent thinkers, philosophers, Nobel laureates, newspaper editors, poets (like Rabindranath Tagore), and scientists. The common thread is her overwhelming love for the land she adopted as her own. They reveal for the first time some unknown incidents during the British Raj, like a private visit to Nivedita by Lady Minto then the Vicerine, who also went to Dakshineshwar temple. Letters were also written to poets, thespians, to famous designer Lalique, William John Warner (better known as Cheiro), who many think predicted to Nivedita her death. The maximum number of letters were written to Josephine Mcleod and Mrs. Ole Bull, American friends of Swami Vivekananda, who helped and supported Sister Nivedita right from her arrival in India. In addition to letters she wrote several books, the most famous of them being, 'The Master as I Saw Him', 'The Web of Indian Life', and 'Studies from an Eastern Home'. ${ }^{6}$ Her writings brought alive the India of that time in its entirety, touching almost all aspects of Indian life. She wrote about her life and activities undertaken in the Bellur Math sometimes making sketches, her journey to Almora, Mother Sharda's affection, Swami Vivekannada's depth of thought, and her observations on the stirring of anti-imperialistic thought in Indian minds.

\section{Propagator of Art and Science}

Nivedita played a crucial role in inspiring Indian artists to rediscover the roots of their own artistic traditions at a time when their practice was largely informed by the traditions of the West. She along with E.B. Havell (principal of the Government School of Art in Calcutta) and Abanindranath Tagore, guided and mentored the NeoIndia art movement that led to the flourishing of what came to be known as the Bengal School of Art. A new generation of young painters grew, and some of the best-known today, like Nandalal Bose, were particularly inspired by her. Nivedita was at the forefront of the movement attacking the then prevalent Western claim that Hellenic art had inspired Indian art, and that there were no real Indian artistic traditions before that. ${ }^{7}$ 

Nivedita stated: "The rebirth of the National Art of India is my dearest dream." Since her stay at Budh-Gaya she had often spoken of the "unity of India," using this phrase as a symbol to transpose her nationalist teaching to a visual level of civic education. $^{8}$

Eminent historian Sabyasachi Bhattacharya says, "She discovered, so to speak, the significance of the Bengal School of painters. She recognised the nationbuilding role of paintings by Abanindranath Tagore - including the famous portrait of Bharat Mata, and it was Nivedita who articulated the personality of a new India in the face of the European hegemony over contemporary Indian imagination."

Nivedita was a great champion of the Tata Institute, which would later become the Indian Institute of Science, in Bengaluru. She wrote about it extensively in the Indian as well as English press, meeting high officials and rallying the support of some of the world's best minds when the British government, under Lord Curzon, scuttled J.N. Tata's proposal of founding a research institute of science and humanities in India. But her more direct contribution was to the career of the pioneering Indian scientist J.C. Bose. She helped him for more than a decade, organizing a steady stream of funds for research, editing and assisting him in the writing of four important books that took his explorations to a world audience, at a time when he faced serious discrimination from the British scientific establishment. ${ }^{10}$ In this sense, Indian renaissance owes considerably to Sister Nivedita as she whole-heartedly supported the revival and infusion of Indian spirit in the arts and science.

\section{An Ardent Supporter of Indian Freedom Movement}

Her Irish background saw her steadily getting drawn into the burgeoning freedom movement even as her love for the country and its people began to manifest through her letters. If one goes through The Statesman between 1904 and 1906 which were watershed years in the Swadeshi Movement, the paper's sympathetic stance towards India and its nationalistic struggle is revealed. There was an unknown force at work here- the letters written by Sister Nivedita to Samuel Ratcliffe, the editor of the paper. For some time, she herself edited a nationalistic paper after Aurobindo Ghosh left for Pondicherry on her advice. In a letter to Ms. Mcleod, Nivedita declared, "The British empire is rotten to the core, without direction, and is tyrannical and mean." ${ }^{11}$ Scathing in her criticism of exploitative British rule, she also actively protested against it.

In 1905, the cataclysmic partition of Bengal galvanized the national consciousness. Through her writing and lectures, Nivedita gave full support to the swadeshi campaign, urging people to go all out in swadeshi-sadhana. Following the Bengal partition, when the government prohibited the singing or chanting of 
Sister Nivedita: The Embracer of India

Sqn. Ldr. Toolika Rani (Retd.)

BandeMataram, Nivedita continued it as part of her school's daily routine. She passionately advocated the idea of worshipping the nation-mother. She held Hindus and Muslims to be children of the same Mother, and in her writings and speeches, exhorted them to together create the Indian nation of the future. ${ }^{12}$ Here she was full force against the British policy of 'Divide and Rule'.

She was possibly the first person to have conceived and designed an emblem and a flag for the Indian nation, way back in 1905. She chose the vajra (thunderbolt). Nivedita's design of two crossed vajras was meant to signify the coordinated and selfless actions of multiple individuals, acting in effect as one national organism. Nivedita had this design embroidered by the girls of her Calcutta school and it was displayed at an exhibition organized by the Indian National Congress in 1906 in Calcutta. Eminent Indians like J.C. Bose (who later made it the emblem of his Bose Institute in Calcutta) started using it, and this idea was also later reflected in the design of India's highest military decoration, the ParamVir Chakra. ${ }^{13}$ Thus, she not only resided in India, she was very much a part of her socio-cultural-political struggle against the foreign domination and subjugation.

\section{A Great Humanitarian}

Nivedita's work as a humanitarian was also remarkable. She put her own life in significant peril on several occasions of great calamity, such as during the plague outbreak in Calcutta in 1899 and the great East Bengal famine of 1906. After her stint in the famine-struck countryside of East Bengal, she contracted a severe form of malaria; it took her months to recover. The malaria impaired her health, eventually leading to her premature death. Rabindranath Tagore, who had seen her from close quarters and "felt her tremendous power", referred to her as "LokaMata" (Mother of the People). ${ }^{14}$

\section{Conclusion}

Embodiment of grace, compassion and fiery ideas, Sister Nivedita was a thinker, social reformer, educator, sanyasini all rolled into one. She embraced India and her people as her own and served them tirelessly till her last breath. For her, the Nobel laureate Rabindranath Tagore wrote, "She had won her access to the inmost heart of our society by her supreme gift of sympathy. She did not come to us with the impertinent curiosity of a visitor, nor did she elevate herself on a special high perch with the idea that a bird's eye view is truer than the human view because of its superior aloofness. She lived our life and came to know us by becoming one of ourselves." 15

To preserve Sister Nivedita's legacy, the state government acquired the house no. 16, at Bosepara Lane, Kolkata where she lived and where she hosted luminaries 
RJPSS Sept. 2020 Vol. XLV No.2, ISSN: (P)0258-1701 (e)2454-3403 Impact Factor: 7.717

https://doi.org/10.31995/rjpss.2020.v45i01.030 such as Rabindranath Tagore, Swami Vivekananda, Aurobindo Ghosh and Jagdish Chandra Bose. The house is being renovated by Ramakrishna Sarada Mission under the supervision by Archeological Survey of India. The Ministry of Culture, Government of India has allocated Rs. 1.35 crore for the restoration. With the restoration work nearing completion, the focus now is on setting up the museum where her personal belongings may also be put on display, for example a small crystal thunderbolt which she always kept in her hand when delivering lectures, her manuscripts, her letters, photographs, and so on." 16

History of Indian Renaissance and freedom struggle is intricately entwined with the efforts of such multi-faceted personalities as Sister Nivedita who with their deep understanding of a nation's soul endeavoured tirelessly to remove the trappings around it and ignite a spirit of self-pride and confidence- ingredients essential to bring long lasting changes. She is an example of a perfect blend of oriental wisdom and occidental forwardness which creates simultaneously a rooted and progressive outlook. This is what is needed irrespective of time and space if a nation wants to progress. Sister Nivedita by embracing the soul of India, revived the refulgence of its countenance by infusing the life force of compassion, reformative energy and catalytic dynamism. The field that was created shall be ploughed by the future generations. We shall imbibe her legacy of reinventing the national spirit, retaining its core but removing the redundant, adopting the relevant and being inclusive, compassionate and humane all the time.

\section{References}

1. BhideNivedita Raghunath, Sister Nivedita: The Dedicated Who Gave Her All to India, Vivekananda Kendra, Kanyakumari, Vivekananda Kendra Prakashan Trust, Chennai, First edition, December 2017, p. 9.

2. Hari R., 'Awake, Awake, Great India', Quotable quotes from BhaginiNivedita's Complete Literary Works, Sri LakshmibaiDharmaprakashan Kochi, p. 13.

3. Dutta Indrani, 'From Sister Nivedita, With Love', The Hindu, November 09, 2017.

4. BhideNivedita Raghunath, Sister Nivedita: The Dedicated Who Gave Her All to India, Vivekananda Kendra, Kanyakumari, Vivekananda Kendra Prakashan Trust, Chennai, First edition, December 2017, pp. 73-74.

5. Dutta Indrani, 'From Sister Nivedita, With Love', The Hindu, November 09, 2017.

6. Dutta Indrani, 'From Sister Nivedita, With Love', The Hindu, November 09, 2017. 
Sister Nivedita: The Embracer of India

Sqn. Ldr. Toolika Rani (Retd.)

7. VinayakLohani, 'Sister Nivedita: The Offered One', Livemint, 28 Oct 2017.

8. ReymondLizelle, 'The Dedicated, A Biography of Nivedita', an Asia Book, The John Day Company, New York, 1953, p. 332.

9. Chattopadhyay SuhridSankar, 'Sister Nivedita's House', Frontline, November 25, 2016.

10. VinayakLohani, 'Sister Nivedita: The Offered One', Livemint, 28 Oct 2017.

11. Dutta Indrani, 'From Sister Nivedita, With Love', The Hindu, November 09, 2017.

12. VinayakLohani, 'Sister Nivedita: The Offered One', Livemint, 28 Oct 2017.

13. VinayakLohani, 'Sister Nivedita: The Offered One', Livemint, 28 Oct 2017.

14. VinayakLohani, 'Sister Nivedita: The Offered One', Livemint, 28 Oct 2017.

15. Hari R., 'Awake, Awake, Great India', Quotable quotes from BhaginiNivedita's Complete Literary Works, Sri LakshmibaiDharmaprakashan Kochi, p. 14.

16. Chattopadhyay SuhridSankar, Sister Nivedita's House, Frontline, November 25, 2016. 